TITLE:

\title{
Dynamic alternation of primate response properties during trial-and-error knowledge updating(Abstract_要旨 )
}

$\operatorname{AUTHOR}(\mathrm{S}):$

Fujimoto, Atsushi

\section{CITATION:}

Fujimoto, Atsushi. Dynamic alternation of primate response properties during trial-anderror knowledge updating. 京都大学, 2013, 博士(医学)

\section{ISSUE DATE:}

2013-07-23

\section{URL:}

https://doi.org/10.14989/doctor.k17819

\section{RIGHT:}

This dissertation is author version of following the journal article. Atsushi Fujimoto, Satoshi Nishida, Tadashi Ogawa, Dynamic alternation of primate response properties during trial-and-error knowledge updating, Robotics and Autonomous Systems, Volume 60, Issue 5, May 2012, Pages 747-753, ISSN 0921-8890, http://dx.doi.org/10.1016/j.robot.2011.06.014. 


\begin{tabular}{|l|l|c|c|}
\hline 京都大学 & 博士 ( 医学 ) & 氏 名 & 藤本 淳 \\
\hline \multirow{3}{*}{ 論文題目 } & $\begin{array}{l}\text { Dynamic alternation of primate response properties during } \\
\text { trial-and-error knowledge updating }\end{array}$
\end{tabular}

論文題目 (試行錯誤による知識の更新に伴うサル眼球運動反応特性の転換)

\section{（論文内容の要旨）}

未知の問題に直面した際、我々は試行錯誤的な探索により問題解決に必要な知識を探し だす (試行錯誤的な探索)。一方で、一旦知識を獲得すれば、同種の問題には知識に基づ いた素早く的確な処理が可能となる（知識に基づく探索）。従うべきルールが変化する環 境に於いて適応的に振る舞うには、これら 2 種類の探索方略を柔軟に使い分けることが必 要である。このような異なる探索方略の転換に関わる神経基盤について調べるには、侵襲 的脳計測が可能であるモデル動物の確立が不可欠と言える。本研究は、サルに変化する環 境を模した行動課題を課し、動物実験モデルを確立することにより、我々の柔軟な適応能 力の解明へ寄与することを目的とした。

雌のニホンザル 1 頭に頭部固定ホルダーおよび眼位測定用コイルを取り付け、視覚探索 課題を訓練した。視覚探索課題では、固視点に続いて6色の異なる色の円で構成された刺 激配列がモニタに呈示される。6色のうち予め決められた 1 色が報酬と結びついた目標色 であり、GO刺激 (固視点の消失) 後すぐにサルが眼球運動によって目標色を選択寸れば、 報酬（ジュース）が与えられた。目標色は明示的に教示されず、サルは正解／不正解のフ イードバックに基づいて自身の選択を評価し、目標色を認識する必要があった。目標色は 試行ブロック（20〜40試行の成功試行）消化後に教示なしに他の色へ変更され、サル はブロックが変更される度に試行錯誤により新たな目標色を探索することを要求された。 サルは目標色が変更されると速やかに試行錯誤的な探索を始め、一度目標色を見つける と直ちに知識に基づく探索を行った。一度目標色を見つけた後の成功率は $86.3 \%$ と高く維 持された。記憶可能な色の数を様々に仮定した成功率シミュレーションの結果から、サル は自身が選んだ色の履歷からどれか 1 つ色を記憶して試行錯誤を行っていたことが示 唆された。

モチベーションや報酬期待值の違いを反映すると考えられる固視点反応潜時 (試行開始 時、モニタ上に固視点が表示されてからサルが視線を固視点へ移すまでの時間）は、試行 錯誤的な探索期間において有意に延長していた。一方で、運動の正確さの指標と考えられ る眼球運動反応潜時（GO刺激呈示から眼球運動が開始されるまでの時間）については、 試行錯誤的な探索期間での延長は見られず、知識に基づく探索期間での失敗試行における 潜時の有意な短縮が観察された。これら反応潜時の違いは、内的な探索方略の性質の違い を反映したものであると考えられた。

さらに、色選択の傾向を調べることで、試行錯誤的な探索期間と知識に基づく探索期間 では異なる選択方略が採られていることが明らかとなった。失敗試行が起こった次の試行 において目標色再選択率（直近で報酬を得た際に選んだ色を再度選択寸る割合）を計算す ると、試行錯誤的な探索期間では次々と選ぶ色を変えていることから目標色再選択率が低 かったのに対し、知識に基づく探索期間では失敗が起こってもすぐに目標色を選び直すた め目標色再選択率が高く維持されており、色選択傾向のステップ状の変化が示された。

これらの結果から、サルが環境からのフィードバック情報に基づき、試行錯詋的な探索 および知識に基づく探索という異なる色選択傾向を持つ探索方略を柔軟に転換し、課題を 遂行することができるという証拠が示され、異なる探索方略に対応する行動学的指標が明 らかとなった。本研究により、変化する環境に於ける柔軟な探索方略の転換に関する動物 モデルが確立され、その基盤となる神経メカニズムの実験的解明一応用可能な成果が得ら れた。
（論文審査の結果の要旨）

本研究は、サルに変化する環境を模した行動課題を課し、試行錯誤的な探索と知識に基 づく探索との行動特性の違いを明らかにすると共に、動物実験モデルを確立することで侵 襲的な神経活動記録を可能とし、我々ヒ卜の柔軟な適応能力の解明へ寄与寸ることを目的 として行われた。

サルに6色の視覚刺激から教示なしに1色の目標色を探索させる視覚探索課題を訓練し たところ、サルは目標色が変更されると速やかに試行錯誤的な探索により新たな目標色を 見つけ出し、1度成功すると知識に基づき同じ色を繰り返し選択するというように、フィ 一ドバックに基づき試行錯㖣的な探索と知識に基づく探索を必要に応じて素早く転換し た。

固視点への反応時間は探索方略によって異なり、眼球運動反応潜時はケアレスミス試行 でのみ短縮していたことから、試行錯誤的な探索は知識に基づく探索とモチベーションに 違いがあるものの、正確な眼球運動を行っている状態であることが示唆された。

これらの結果より、変化する環境での柔軟な適応に必須である2つの探索方略に関する 行動特性が明らかとなり、神経メカニズムを調べるうえで有用な動物モデルを確立するこ とが出来た。

以上の研究は、変化する環境に於ける探索方略の転換メカニズムの解明に貢献し、神経科 学の進歩、発展に寄与するところが多い。したがって、本論文は博士 (医学) の学位論文 として価值あるものと認める。なお、本学位授与申請者は、平成 25 年 6 月 3 日実施の詥 文内容とそれに関連した試問を受け、合格と認められたものである。 